\title{
A Missed Date
}

Timothy Kuchera, MD

"You're a DOCTOR, NOT a CLERK," bellowed my attending as I blinked with bloodshot, sunken eyes. "So use your BRAIN like a DOCTOR!" It was February of my intern year. At this point, I was exhausted and emotionally drained. I had minimal contact with friends and family and lost all ability to converse with those outside of medicine. My favorite hobbies now included repleting daily potassium and ensuring that my patients had regular bowel movements. Honestly, I got so good by the end of the year that just by walking down the hallway, my patients would experience a rectocolic reflex and a symphony of call bells would fill the air. It was music to my ears. It was during this unique and trying time in my life that I met a patient named Mary.

Mary's admission was abrupt and unexpected. She was 69 years old and had been otherwise healthy until she presented with two weeks of fevers and fatigue. On admission, she was found to be pancytopenic, and a bone marrow biopsy was performed. Shortly thereafter, Mary was diagnosed with Hemophagocytic Lymphohistiocytosis, also known as HLH, in addition to a very rare T-cell lymphoma. HLH is an aggressive and life-threatening syndrome of excessive immune activation. A diagnosis with $\mathrm{HLH}$ can drastically cut life expectancy. Mary's dual diagnoses of HLH with T-cell Lymphoma reduced her life expectancy to one to two months. Despite the overwhelming odds, like any family struck with this sudden news, Mary and her family were hopeful that prompt treatment would alter the course of her illness and reach a cure.

In spite of her grave prognosis, I was struck by the life and energy that Mary exuded. Even at the age of 69 with multiple organ failure, she would greet me every morning with an energetic, "GOOD MORNING, BABY!" She constantly joked with the nurses, residents and attending physicians. She was a favorite patient among staff. Everyone was pulling for her. One morning out of the blue, Mary asked me where I was taking her on our first date. Completely caught off guard I sputtered, "Well, where do you want to go?" "I don't know!" She shot back, "But if it ain't somewhere nice, you and me are through!" When my attending heard about this, she stated that Mary had the worst case of steroid-induced psychosis she had ever seen..

It seemed Mary's spirit could not be extinguished. Diagnosed with HLH? Bring it on. Lymphoma? Whatever.
Gl bleed? Flirt with the Gl fellow. One morning, a rapid response was called for syncope. By the time I arrived, she recovered and was cracking jokes with the residents and nursing staff. In even the most desperate of times, she maintained her enthusiasm and lightheartedness.

Unfortunately, this story ends the way you probably expected. One morning, Mary was transferred to the ICU for emergent dialysis. From there on, her clinical course took a precipitous turn. The HLH, lymphoma, Gl bleed, UTI, pneumonia, liver failure, and kidney failure compounded, and Mary and her family decided that they had enough. For four weeks, Mary was poked, prodded, biopsied, imaged, dialyzed, and filled with cytotoxic chemicals. A mutual decision was made to pursue comfort measures and have Mary spend her final days in the company of her family. Coincidentally, this decision came on the final day of my oncology rotation. I had not seen Mary since her transfer to the ICU and when I stepped into her room I barely recognized her. The previously raucous, animated, jubilant Mary now lay cachectic and motionless in her hospital bed. I stumbled over my words as I filled the silence with superficial conversation. I began to experience overwhelming feelings of loss and despair as I realized our time was short. I missed the energetic person I had come to know and care for one month prior. If I could just see her laugh, I thought, maybe everything would be okay. I asked, "Mary, where are we going on our date?" What I hoped for was a quip. What I hoped was for Mary to spring back to life. Instead, I got something much different. She slowly shifted her gaze to mine, pointed at the sky and whispered, "In Heaven." I attempted to collect myself and managed to choke out, "Well you better pick somewhere good!" "Don't worry," she said. "I'll have plenty of time."

Despite our efforts, Mary passed away on April 9th, 2017. I am grateful for Mary. Her love and passion for life were infectious and I am very fortunate to not only have met her but to care for her as her doctor. Caring for Mary was a privilege and truthfully reminded me of my humanity. Doctors and nurses have all experienced that medicine can be a draining and potentially jading profession. My hope is that my colleagues have the opportunity to experience rejuvenating and heartwarming people in their practice like Mary; both in the patients they treat and the people they work with. 